\title{
Jaboticaba yoghurts enriched with whey protein or albumin: evaluation of phenolic content and color*
}

\author{
logurtes de jabuticaba adicionados de proteína do soro \\ do leite ou albumina: avaliação do conteúdo fenólico e cor
}

\author{
Claudia de Abreu Marques Coentrão, ${ }^{* *}$ Eliane Teixeira Mársico, ${ }^{* *}$ Beatriz da Silva Frasao, ${ }^{* *}$ \\ Roberta de Oliveira Resende Ribeiro, ${ }^{* *}$ Lismaíra Gonçalves Caixeta Garcia, ${ }^{* * *}$ Flávio Alves da Silva, ${ }^{* * *}$ \\ Adriano Gomes da Cruz, ${ }^{* * *}$ Julia Siqueira Simoes, ${ }^{* *}$ Adriana Cristina de Oliveira Silva**
}

\begin{abstract}
In the present study, nonfat yoghurt made with whey protein isolate (WPI) or pasteurized egg white powder (albumin) was added with syrup containing jaboticaba pulp and lyophilized jaboticaba peel flour and six experimental groups were made: control yoghurt (CY); WPI yoghurt (WY); albumin yoghurt (AY), syrup yoghurt and WPI (WSY); syrup and albumin yoghurt (ASY) and syrup yoghurt (SY). This study aimed to verify the influence of the addition of fruit syrup on the phenolics compounds and on the instrumental color parameters of yoghurts made with proteins on the $1^{\text {st }}$ and $28^{\text {th }}$ day of storage. There was a significant decrease in total phenolics content in yoghurt containing WPI and syrup (from 1408.14mg GAE.L-1 to 686.73mg GAE.L-1), as well as total anthocyanin content. However, yoghurt containing syrup and albumin showed an increase in total flavonoid content on day 28 of storage (from $28.30 \mathrm{mg} \mathrm{QE} .100 \mathrm{~g}^{-1}$ to $38.29 \mathrm{mg} \mathrm{QE} .100 \mathrm{~g}^{-1}$ ). Regarding color, there was an increase in $\mathrm{L}^{*}$ and $b^{*}$ values in yoghurt containing syrup and WPI and in yoghurt containing syrup and albumin. For $a^{*}$ values, a decrease was observed at the end of the storage period in samples containing protein (WPI or albumin) and syrup. The data showed that the addition of jaboticaba syrup to yoghurts containing different proteins provided different phenolics compounds contents at the end of the storage period, and different color parameters to the final product.
\end{abstract}

Keywords: native fruit, fermented milk, polyphenols, proteins.

\section{Resumo}

No presente estudo, iogurtes desnatados feitos com proteína isolada do soro do leite (PIS) ou albumina isolada da clara do ovo pasteurizada em pó (albumina) foram adicionados de xarope contendo a polpa da jabuticaba e a farinha liofilizada da casca da jabuticaba, obtendo-se seis grupos experimentais: iogurte controle (CY); iogurte PIS (WY); iogurte albumina (AY); iogurte xarope e PIS (WSY); iogurte xarope e albumina (ASY) e iogurte com xarope (SY). Neste estudo objetivou-se verificar a influência da adição do xarope da fruta nos compostos fenólicos e nos parâmetros instrumentais de cor dos iogurtes elaborados com proteínas no $1^{\circ}$ e $28^{\circ}$ dia de armazenamento. Houve uma diminuição significativa no teor de fenólicos totais no iogurte contendo PIS e xarope (de 1408.14mg GAE.L-1 para 686.73mg GAE.L-1), bem como no teor de antocianinas (de 158.45mg cyanidin-3-glucoside.L-1 para $56.45 \mathrm{mg}$ cyanidin-3-glucoside. $\mathrm{L}^{-1}$ ). No entanto, os iogurtes contendo xarope e albumina apresentaram um aumento no teor de flavonóides totais no $28^{\circ}$ dia de armazenamento (de $28.30 \mathrm{mg} \mathrm{QE} 100 \mathrm{~g}^{-1}$ para $38.29 \mathrm{mg} \mathrm{QE} 100 \mathrm{~g}^{-1}$ ). Em relação a cor houve um aumento dos valores de $L^{*}$ e no valor de $b^{*}$ no iogurte contendo xarope e PIS e no iogurte contendo xarope e albumina. Já para os valores de $a^{*}$ foi observado uma diminuição ao final do período de armazenamento nas amostras contendo proteína (PIS ou albumina) e xarope. Os dados demonstraram que a adição do xarope de jabuticaba a iogurtes contendo diferentes proteínas proporcionaram diferentes conteúdos de compostos fenólicos ao final do período de estocagem, e diferentes parâmetros de cor ao produto final.

Palavras-chave: fruta nativa, leites fermentados, polifenóis, proteínas

\footnotetext{
${ }^{*}$ Recebido em 13 de novembro de 2019 e aceito em 6 de dezembro de 2019.

**Fluminense Federal University, Niterói - Rio de Janeiro, code 24230-340.

***Federal University of Goiás, code, 74690-900, Goiás, Brazil.

${ }^{* * *}$ Federal Education Institute, Maracanã - Rio de Janeiro, code 20260-100, Brazil.

Corresponding author: cacau.coentrao@gmail.com (MSc. Claudia de Abreu Marques Coentrão). Phone: +55 21 99510-3372.
} 


\section{Introduction}

Yoghurt is one of the most popular fermented dairy products worldwide and fruits addition can improve nutritional quality such as fibers and natural antioxidants (Scibisz et al., 2019).

A native purple berry from Brazil, Jaboticaba (Myrciaria jaboticaba - Vell) Berg - Jaboticaba Sabará), is rich in phenolic compounds including jaboticabin, flavonoids, anthocyanins, tannins, and others, mostly found in peel (Romão et al., 2019). The incorporation of ingredients with high antioxidant and antiinflammatory activities, as dried jaboticaba peel, can increase nutritional value and functional properties in food (Di Maio et al., 2019).

Considering functional properties, whey protein and its bioactive compounds are other ingredients that can improve the quality of the food, especially dairy products. When this byproduct is added to yoghurt increases protein concentration contributing with nutritional quality and desirable technological e sensory properties (Delikanli and Ozcan, 2016).

Another important protein source widely used by food industries because its versatility and technological proprieties are egg white (Singh et al., 2019). Furthermore, egg white is rich in functional peptides and when associated with a healthy diet contributes to the prevention and treatment of some diseases (Chen Chi et al., 2012).

Certain proteins are known to interact with the amount of phenolic compounds (Ulrih, 2015). In addition, there are no studies with dairy products using jaboticaba flour peel as an ingredient and albumin.

For that reason, the present study is an original work and aimed to evaluate the effect of the addition of lyophilized jaboticaba peel flour and jaboticaba pulp (syrup) on phenolic content and instrumental color parameters of nonfat yoghurt made with whey protein isolate (WPI) or pasteurized egg white powder albumin (albumin) stored at $4 \pm 1{ }^{\circ} \mathrm{C}$ for 28 days.

\section{Materials and methods}

\section{Chemicals}

Ethyl alcohol (PubChem CID: 702) 200 Proof (C3H3C2H2OH), gallic acid (PubChem CID: 370), tannic acid (PubChem CID: 16129778), quercetin (PubChem CID: 5280343), Folin-Ciocalteu's phenol reagent (PubChem CID: 6037), aluminum chloride (AICI3) (PubChem CID: 24012), poly (vinylpolypyrrolidone) (PVPP) (PubChem CID: 6917), potassium chloride $(\mathrm{KCl})$ (PubChem CID: 4873), sodium acetate (CH3COONa.3H2O) (PubChem CID: 517045), potassium acetate (CH3COOK) (PubChem CID: 517044), sodium carbonate (Na2CO3) (PubChem CID: 10340) were used.

\section{Plant material}

Fruits (Myrciaria jaboticaba (Vell.) Berg) (Jaboticaba Sabará) were collected in Farm and Winery Jaboticabal (Hidrolândia, Goiás, Brazil). They were selected, washed in tap water, sanitized with sodium hypochlorite solution $100 \mu \mathrm{L} . \mathrm{L}^{-1}$ for 15 minutes. Pulp, peel, and seeds were separated using an electronic device $\left(\mathrm{DHM}-2\right.$, Macanuda ${ }^{\circledR}$ ). After, the jaboticaba peel and jaboticaba pulp were separately frozen in a conventional freezer for 24 hours $\left(-18^{\circ} \mathrm{C}\right)$ and transported to the Fruit and Vegetables Processing Laboratory of the Faculty of Food Engineering of Goiás Federal University. Then, the jaboticaba peel was freeze-dried in a freeze-drier (Terroni ${ }^{\circledR}$ LS 3000) for about 48h. After freezedrying, the samples were ground to obtain freeze-dried powder (Inada et al., 2015). In total, approximately $1 \mathrm{~kg}$ of jaboticaba pulp and $500 \mathrm{~g}$ of lyophilized jaboticaba peel flour were used in the experiment.

\section{Ingredients}

To perform treatments, it was used white cane sugar (União ${ }^{\circledR}$ ), UHT skimmed milk (Molico ${ }^{\circledR}$ ), albumin isolated pasteurized egg white powder (NaturOvos ${ }^{\circledR}$ ), whey protein isolate - WPI (Isofort ${ }^{\circledR}$ ). Ingredients were purchased from a local supermarket at Niterói, RJ, Brazil. Starter cultures of Streptococcus thermophilus and Lactobacillus bulgaricus subsp. delbrueckii (Yo-Flex ${ }^{\circledR}, \mathrm{Chr}$ Hansen, Valinhos, SP, Brazil) were used.

\section{Syrup and yoghurt preparation}

For the syrup formulations, jaboticaba pulp (20\%), freeze-dried jaboticaba peel flour $(2 \%)$ and sugar $(5 \%)$ were mixed and pasteurized at $60^{\circ} \mathrm{C}$ for $3 \mathrm{~min}$. The syrups to be added to the control yoghurt $(\mathrm{CY})$ and syrup yoghurt $(\mathrm{SY})$ were added $1 \%$ water in its formulation.

Yoghurts were produced using UHT skimmed milk and freezedried starter cultures $(2 \% \mathrm{w} / \mathrm{v})$ corresponding approximately to $7 \log _{10}$ CFU g-1 of a mixed culture of Streptococcus thermophilus and Lactobacillus bulgaricus subsp. delbrueckii. After that, yoghurts were incubated at $43^{\circ} \mathrm{C}$ for 4 hours until $\mathrm{pH} 4.6$ and then cooled overnight at $3-5^{\circ} \mathrm{C}$ (Costa et al., 2017).

Control yoghurt $(72 \%)$ sample $(C Y)$ and five treatments were performed as follows: yoghurt (72\%) with WPI (1\%) (WY); yoghurt $(72 \%)$ added of albumin $(1 \%)(A Y)$; yoghurt $(72 \%)$ with syrup (SY); yoghurt (72\%) with WPI (1\%) and syrup (WSY); and yoghurt $(72 \%)$ added of albumin $(1 \%)$ and syrup (ASY). For yoghurts containing protein sources (WPI or albumin), those ingredients were added before the freeze-dried culture inoculation. The syrup was added after yoghurt preparation. All experimental groups were stored at $4 \pm 1^{\circ} \mathrm{C}$ for 28 days.

\section{Determination of total phenolics flavonoids and total anthocyanins content}

The total phenolics content (TPC) was determined at day 1 and day 28 of storage $\left(4 \pm 1^{\circ} \mathrm{C}\right)$ using Folin-Ciocalteu's reagent according to Ainsworth and Gillespie (2007). For that, $0.02 \mathrm{~mL}$ of each sample and $2 \mathrm{~mL}$ methanol $95 \%(\mathrm{v} / \mathrm{v})$ were placed in test tubes. Tubes were vortexed and incubated at room temperature $\left(25^{\circ} \mathrm{C} \pm 2^{\circ} \mathrm{C}\right)$ for 48 hours in a dark place. After, samples were centrifuged (13.000 $\mathrm{g}$ for $5 \mathrm{~min}$ at room temperature) and a $100 \mu \mathrm{l}$ supernatant aliquot was placed in a $2 \mathrm{~mL}$ microtube. Then, $200 \mu \mathrm{L}$ of $10 \%(v / v)$ Folin-Ciocalteu's reagent was added and vortexed followed by the addition of $800 \mu \mathrm{L}$ sodium carbonate $700 \mathrm{mM}$ $\left(\mathrm{Na}_{2} \mathrm{CO}_{3}\right)$. Microtubes were incubated in a dark place at room temperature $\left(25 \pm 2^{\circ} \mathrm{C}\right)$ for 2 hours.

For absorbance readings, it was used a spectrophotometer UV1800 (Shimadzu $^{\circledR}$ Corporation, Kyoto, Japan) at $765 \mathrm{~nm}$. The gallic acid calibration curve was performed to determine TPC. Results were expressed as milligram gallic acid equivalents (GAE). $100 \mathrm{~g}^{-1}$ sample. 
Determination of total flavonoids content (TFC) at day 1 and day 28 of storage $\left(4 \pm 1^{\circ} \mathrm{C}\right)$ was according to Lin and Tang (2007). For that, $0.1 \mathrm{~g}$ of sample was dissolved in $1 \mathrm{~mL}$ deionized water. Then, $0.5 \mathrm{~mL}$ was mixed with $1.5 \mathrm{~mL}$ of $95 \%$ alcohol, $0.1 \mathrm{~mL}$ of $10 \%$ aluminum chloride hexahydrate $\left(\mathrm{AlCl}_{3} 6 \mathrm{H}_{2} \mathrm{O}\right), 0.1 \mathrm{~mL}$ of $1 \mathrm{M}$ potassium acetate $\left(\mathrm{CH}_{3} \mathrm{COOK}\right)$ and $2.8 \mathrm{~mL}$ of deionized water. The samples were incubated at room temperature $\left(25 \pm 2^{\circ} \mathrm{C}\right)$ in a dark room for 40 minutes.

The absorbance was measured at $415 \mathrm{~nm}$ in a Spectrophotometer UV-1800 (Shimadzu ${ }^{\circledR}$ Corporation, Kyoto, Japan) using deionized water as a blank and quercetin were chosen as a standard. Data were expressed as milligram quercetin equivalents (QE). $100 \mathrm{~g}^{-1}$.

Total anthocyanins content (TAC) was determined at day 1 and day 28 of storage $\left(4 \pm 1^{\circ} \mathrm{C}\right)$ as described by Lee et al. (2005). For the Research Project Approval Certificate issued by the Animal Use Ethics Committee was 45956615.5.0000.5243.

\section{Results and discussion}

Total phenolics (TPC), total flavonoids (TFC) and total anthocyanins (TAC) content

The TPC results obtained from yoghurt samples are displayed in table 1. The highest concentration at the beginning storage

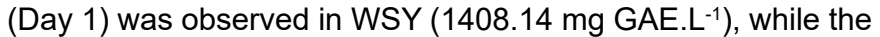
lowest concentration was determined in WY (316.95 mg GAE. $\left.\mathrm{L}^{-1}\right)$ instead of control samples (338.30 mg GAE.L-1).

In addition, a significant decrease $(P<0.05)$ in TPC was observed in all yoghurts added with syrup and in the syrup during storage.

Table 1: Total Phenolics Content (TPC; mg GAE. $\left.\mathrm{L}^{-1}\right)(\mathrm{Mean} \pm \mathrm{SD})$ of syrup, control sample and five treatments on the $1^{\text {st }}$ and $28^{\text {th }}$ days of refrigerated $\left(4 \pm 1^{\circ} \mathrm{C}\right)$ storage

\begin{tabular}{cccccccc}
\hline Day & Syrup & CY & SY & WY & WSY & AY & ASY \\
\hline 1 & $3934.70 \pm 1.10^{\mathrm{C}}$ & $338.30 \pm 0.73^{\mathrm{bA}}$ & $1130.68 \pm 1.68^{\mathrm{aA}}$ & $316.95 \pm 0.99^{\mathrm{bA}}$ & $1408.14 \pm 1.60^{\mathrm{aA}}$ & $388.99 \pm 0.79^{\mathrm{bA}}$ & $1073.32 \pm 1.11^{\mathrm{aA}}$ \\
28 & $3168.30 \pm 1.00^{\mathrm{D}}$ & $268.93 \pm 0.48^{\mathrm{bA}}$ & $672.32 \pm 1.27^{\mathrm{aB}}$ & $260.93 \pm 0.42^{\mathrm{bA}}$ & $686.73 \pm 1.82^{\mathrm{aB}}$ & $262.53 \pm 0.59^{\mathrm{bA}}$ & $537.86 \pm 1.60^{\mathrm{aB}}$ \\
\hline
\end{tabular}

$a-b$ means in the same row (comparing treatments) exhibiting different superscript letters are different $(P<0.05)$. A-D means in the same column (comparing 1st and 28th day) with different superscript letters are different $(P<0.05)$. SD = standard deviation. Determination in three batches (genuine replicates). (CY) control yoghurt, (SY) yoghurt with syrup, (WY) yoghurt with WPI, (WSY) yoghurt with WPI and syrup, (AY) yoghurt with albumin, (ASY) yoghurt with albumin and syrup.

that, $10 \mathrm{mg}$ sample was mixed with $40 \mathrm{~mL}$ of $0.025 \mathrm{M}$ potassium chloride buffer ( $\mathrm{pH} 1.0)$; and another $10 \mathrm{mg}$ sample was added of $40 \mathrm{~mL}$ of $0.4 \mathrm{M}$ sodium acetate buffer $(\mathrm{pH} 4.5)$. The $\mathrm{pH}$ values for buffer solutions were measured using a pHmeter (Hanna Instruments ${ }^{\circledR}$ ) calibrated at $\mathrm{pH} 4.01$ and 6.86 , adjusted with $1 \mathrm{~N}$ $\mathrm{HCl}$. Each solution was incubated in a dark room at $25 \pm 2^{\circ} \mathrm{C}$ for 20-50 minutes. The absorbance reading was at $520 \mathrm{~nm}$ and $700 \mathrm{~nm}$, respectively, using a Spectrophotometer UV-1800 (Shimadzu ${ }^{\circledR}$ Corporation, Kyoto, Japan). The final volume over the original sample volume (dilution factor) was determined the dilution factor. The anthocyanin content was calculated as cyanidin-3-glycoside, and the results were expressed as cyanidin-3-glucoside equivalents in $\mathrm{mg} \cdot \mathrm{L}^{-1}$.

\section{Color measurements}

Color measurements were performed at day 1 and day 28 of storage $\left(4 \pm 1^{\circ} \mathrm{C}\right)$ using a portable colorimeter (CR-410, Konica Minolta Sensing ${ }^{\circledR}$, Inc., Tokyo, Japan). The coordinates $L^{*}$, $a^{*}$, and $b^{*}$ were determined using the CIE scale, where $L^{*}$ is a measure of lightness, $a^{*}$ varies from green $(-)$ to red $(+)$ and $b^{*}$ varies from blue (-) to yellow (+) using D65 illuminant in a $10^{\circ}$ observer angle.

\section{Statistical analysis}

Three batches (genuine replicates) of yoghurts processing were performed for each treatment group. Mean values and standard deviations (SD) were reported for chemical and colorimetric analysis and the comparison between means was performed using a one-way analysis of variance (ANOVA) followed by Tukey's test $(P<0.05)$. Data of phenolic contents $(T P C, T F C$, and TAC) and color parameters were analyzed using a commercially available statistical package (XLSTAT version 2015.6 for Windows, Addinsoft, Long Island City, NY, USA). The number of
This result is probably due to the formation of protein-polyphenol complexes, leading to phenolics compounds reduction. The complexation depends on several factors such as the type of protein, polyphenols structure, the system temperature and the presence of components like sugar or polysaccharides (Demirkol and Tarakci, 2018). However, proline residues are important to promote an open protein structure which allows a greater binding to phenolic content (Yildirim-Elikoglu and Erdem, 2017).

As expected, when comparing experimental groups on the same day, TPC values were higher on formulations with added fruit syrup, than levels observed on treatments without jaboticaba syrup. Some authors found significantly higher total phenolics in yoghurts supplemented with grape seed or callus extracts (Chouchouli et al., 2013; Mercan et al., 2017; De Souza de Azevedo et al., 2018; Demirkol and Tarakci, 2018).

Researchers observed polyphenols content and antioxidant activity in milk and dairy products (Lee et al., 2017; Lanni et al., 2019). The same was observed in this research once TPC values were found in yoghurts without fruit syrup (CY, WY, and AY). The content of total phenolics compounds present in yoghurts containing proteins (WPI or albumin) but not added to fruit syrup did not differ statistically on the first storage day and the same was observed on the $28^{\text {th }}$ day. Although no significative difference $(P>0.05)$ was observed, the reduced TPC on WY samples could be due to a high affinity of some polyphenols for whey proteins, leading to complexation of molecules (De Souza de Azevedo et al., 2018).

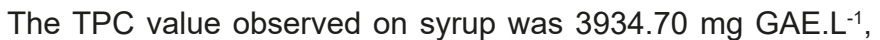
lower than those concentrations reported by Abe et al. (2011) in jaboticaba fruit $\left(7.44 \pm 0.32 \mathrm{~g}\right.$ GAE. $\left.\mathrm{L}^{-1}\right)$. This could be probably due to the heating process during syrup preparation, once phenolics compounds are highly sensitive to external factors like temperature and pressure. 
The temperature may affect the biological activity and cause structure modifications on TPC (M'hiri et al., 2015). To corroborate, Reis et al. (2013) reported that Cumari Peppers dried at high temperatures showed a significative decrease in phenolics content. However, the formed complexes of protein and polyphenol do not necessarily reduce the bioavailability of such polyphenols (Demirkol and Tarakci, 2018).

Concerning the TFC (Table 2), there was a decrease in the experimental groups CY, SY, WY and WSY at the end of the storage period but it was not significant. In contrast, there was a significant difference $(P<0.05)$ in yoghurts containing albumin, which increased $60.03 \%$ (AY) and $35.31 \%$ (ASY), possibly due to flavonoids glycosylation (Xiao et al., 2011).

Studies have shown flavonoids compounds in jaboticaba fruit (Myrciaria cauliflora) and sugar content may be associated with most of these compounds (Kim et al., 2015). Flavonoids with monoglycosides on its structure have stronger binding affinities with milk proteins than those polyglycosides structures (Xiao et al., 2011). On flavonoids glycosylation, a hydroxyl group is replaced by a modified structure of glycoside, decreasing binding affinities for whey proteins (Xiao et al., 2009).

Anthocyanins content has been described in the fruit and peel, specially cyanidin and delphinidin 3-glucosides, which presents antioxidant, antiproliferative and antimutagenic activities (Leite-
Legatti et al., 2012). In this study, the TAC level (Table 3) of syrup was 1000.02 mg cyanidin-3-glucoside.L-1 in the first day of storage. A similar result was observed by Leite-Legatti et al. (2012) on freeze-dried jaboticaba peel $\left(1514.82 \mathrm{mg}^{100 \mathrm{~g}^{-1}}\right.$ of cyanidin-3-O-glucoside). It is worth to notice that added syrup treatments (SY, WSY, ASY) showed increased concentration comparing to yoghurts without syrup. Once more, these results support the important content of anthocyanin on jaboticaba peels, since the anthocyanin content in the pulp is not significant.

No significant differences were observed for the content of total anthocyanins of the yoghurts containing syrup at the first day of storage, which was also observed for the yoghurts without the addition of fruit syrup, which remained constant up to the 28th day. However, after 28 days of storage, there was a significant decrease $(P<0.05)$ of total anthocyanins content on yoghurts produced with fruit syrup (SY, WSY, ASY). According to Silva et al. (2017), anthocyanins stability may be affected by several factors such as enzyme influences, light influence, temperature, and the chemical reactions lead to either the consumption or the destabilization of anthocyanins during storage.

\section{Color measurements}

The color measurements obtained from yoghurt samples are displayed in tables 4,5 and 6 .

Table 2: Total Flavonoids Content (TFC; mg QE. $\left.100 \mathrm{~g}^{-1}\right)($ Mean $\pm \mathrm{SD})$ of the treatments and syrup on the $1^{\text {st }}$ and $28^{\text {th }}$ days of refrigerated $\left(4 \pm 1^{\circ} \mathrm{C}\right)$ storage

\begin{tabular}{cccccccc}
\hline Day & Syrup & CY & SY & WY & WSY & AY & ASY \\
\hline 1 & $65.93 \pm 0.28^{\mathrm{C}}$ & $24.15 \pm 0.46^{\mathrm{bcA}}$ & $30.93 \pm 0.88^{\mathrm{abA}}$ & $27.15 \pm 0.46^{\mathrm{bcA}}$ & $43.13 \pm 0.83^{\mathrm{aA}}$ & $15.82 \pm 0.80^{\mathrm{cB}}$ & $28.30 \pm 0.70^{\mathrm{bcB}}$ \\
28 & $30.74 \pm 0.44^{\mathrm{D}}$ & $21.78 \pm 0.96^{\mathrm{bA}}$ & $25.64 \pm 0.04^{\mathrm{bA}}$ & $21.52 \pm 0.59^{\mathrm{bA}}$ & $39.59 \pm 0.59^{\mathrm{aA}}$ & $25.32 \pm 0.06^{\mathrm{bA}}$ & $38.29 \pm 0.44^{\mathrm{aA}}$ \\
\hline
\end{tabular}

a-c means in the same row (comparing treatments) exhibiting different superscript letters are different $(P<0.05)$. A-D means in the same column (comparing 1st and 28th day) with different superscript letters are different $(P<0.05)$. SD = standard deviation. Determination in three batches (genuine replicates). (CY) control yoghurt, (SY) yoghurt with syrup, (WY) yoghurt with WPI, (WSY) yoghurt with WPI and syrup, (AY) yoghurt with albumin, (ASY) yoghurt with albumin and syrup.

Table 3: Total Anthocyanins Content (TCA; mg cyanidin-3-glucoside. L-1) $^{-1}$ (Mean $\pm S D$ ) of syrup, control sample and five treatments on the $1^{\text {st }}$ and $28^{\text {th }}$ day of refrigerated $\left(4 \pm 1^{\circ} \mathrm{C}\right)$ storage

\begin{tabular}{cccccccc}
\hline Day & Syrup & CY & SY & WY & WSY & AY & ASY \\
\hline 1 & $1000.02 \pm 0.41^{\mathrm{C}}$ & $2.27 \pm 0.37^{\mathrm{bB}}$ & $156.67 \pm 0.83^{\mathrm{aA}}$ & $2.27 \pm 0.57^{\mathrm{bB}}$ & $158.45 \pm 1.60^{\mathrm{aA}}$ & $0.40 \pm 0.12^{\mathrm{bB}}$ & $163.03 \pm 1.21^{\mathrm{aA}}$ \\
28 & $764.25 \pm 0.81^{\mathrm{D}}$ & $3.61 \pm 0.37^{\mathrm{bA}}$ & $49.62 \pm 0.83^{\mathrm{aB}}$ & $6.98 \pm 0.57^{\mathrm{bA}}$ & $56.45 \pm 1.60^{\mathrm{aB}}$ & $2.40 \pm 0.12^{\mathrm{bA}}$ & $58.60 \pm 1.24^{\mathrm{aB}}$ \\
\hline
\end{tabular}

$a-b$ means in the same row (comparing treatments) exhibiting different superscript letters are different $(P<0.05)$. A-D means in the same column (comparing 1st and 28th day) with different superscript letters are different $(P<0.05)$. SD $=$ standard deviation. Determination in three batches (genuine replicates). (CY) control yoghurt, (SY) yoghurt with syrup, (WY) yoghurt with WPI, (WSY) yoghurt with WPI and syrup, (AY) yoghurt with albumin, (ASY) yoghurt with albumin and syrup.

Table 4: Color measurements $L^{*}($ Mean $\pm S D)$ of the yoghurts on the $1^{\text {st }}$ and $28^{\text {th }}$ day of refrigerated $\left(4 \pm 1^{\circ} \mathrm{C}\right)$ storage

\begin{tabular}{ccccccc}
\hline Day & CY & SY & WY & WSY & AY & ASY \\
\hline $1^{\text {st }}$ & $80.41 \pm 0.26 \mathrm{aA}$ & $39.36 \pm 1.33 \mathrm{bB}$ & $80.39 \pm 0.18 \mathrm{aA}$ & $39.23 \pm 1.53 \mathrm{bB}$ & $80.59 \pm 0.23 \mathrm{aA}$ & $40.22 \pm 0.83 \mathrm{bB}$ \\
$2^{\text {th }}$ & $79.49 \pm 0.21 \mathrm{aB}$ & $41.44 \pm 0.98 \mathrm{cA}$ & $79.44 \pm 0.24 \mathrm{aB}$ & $41.83 \pm 0.70 \mathrm{bA}$ & $79.27 \pm 0.56 \mathrm{aB}$ & $42.57 \pm 0.51 \mathrm{bA}$ \\
\hline
\end{tabular}

a-c means in the same row (comparing treatments) exhibiting different superscript letters are different (P<0.05). A-B means in the same column (comparing 1st and 28th day) with different superscript letters are different $(P<0.05)$. SD $=$ standard deviation. Determination in three batches (genuine replicates). (CY) control yoghurt, (SY) yoghurt with syrup, (WY) yoghurt with WPI, (WSY) yoghurt with WPI and syrup, (AY) yoghurt with albumin, (ASY) yoghurt with albumin and syrup. 
Table 5: Color measurements $a^{*}($ Mean $\pm S D)$ of the yoghurts on the $1^{\text {st }}$ and $28^{\text {th }}$ day of refrigerated $\left(4 \pm 1^{\circ} \mathrm{C}\right)$ storage

\begin{tabular}{ccccccc}
\hline Day & CY & SY & WY & WSY & AY & ASY \\
\hline $1^{\text {st }}$ & $-1.72 \pm 0.05 \mathrm{aB}$ & $12.95 \pm 0.69 \mathrm{bA}$ & $-1.64 \pm 0.07 \mathrm{aB}$ & $13.92 \pm 1.10 \mathrm{cA}$ & $-1.55 \pm 0.09 \mathrm{aB}$ & $13.11 \pm 0.55 \mathrm{bcA}$ \\
$2^{\text {th }}$ & $-1.12 \pm 0.12 \mathrm{aA}$ & $10.00 \pm 1.55 \mathrm{bB}$ & $-1.10 \pm 0.13 \mathrm{aA}$ & $9.79 \pm 1.34 \mathrm{bB}$ & $-0.91 \pm 0.36 \mathrm{aA}$ & $9.27 \pm 1.42 \mathrm{bB}$ \\
\hline
\end{tabular}

a-c means in the same row (comparing treatments) exhibiting different superscript letters are different $(P<0.05)$. A-B means in the same column (comparing 1st and 28th day) with different superscript letters are different $(P<0.05)$. SD $=$ standard deviation. Determination in three batches (genuine replicates). (CY) control yoghurt, (SY) yoghurt with syrup, (WY) yoghurt with WPI, (WSY) yoghurt with WPI and syrup, (AY) yoghurt with albumin, (ASY) yoghurt with albumin and syrup.

Table 6: Color measurements $b^{*}($ Mean $\pm S D)$ of the yoghurts on the $1^{\text {st }}$ and $28^{\text {th }}$ day of refrigerated $\left(4 \pm 1^{\circ} \mathrm{C}\right)$ storage

\begin{tabular}{ccccccc}
\hline Day & CY & SY & WY & WSY & AY & ASY \\
\hline $1^{\text {st }}$ & $5.76 \pm 0.29 \mathrm{bB}$ & $0.39 \pm 0.01 \mathrm{cB}$ & $6.07 \pm 0.16 \mathrm{aB}$ & $0.21 \pm 0.01 \mathrm{cB}$ & $6.29 \pm 0.26 \mathrm{aB}$ & $0.82 \pm 0.67 \mathrm{~dB}$ \\
\hline $28^{\text {th }}$ & $6.85 \pm 0.38 \mathrm{aA}$ & $3.67 \pm 0.66 \mathrm{bA}$ & $6.97 \pm 0.09 \mathrm{aA}$ & $3.48 \pm 0.41 \mathrm{bA}$ & $7.31 \pm 0.40 \mathrm{aA}$ & $3.31 \pm 0.29 \mathrm{bA}$ \\
\hline
\end{tabular}

a- $d$ means in the same row (comparing treatments) exhibiting different superscript letters are different $(P<0.05)$. A-B means in the same column (comparing 1st and 28th day) with different superscript letters are different $(P<0.05)$. SD = standard deviation. Determination in three batches (genuine replicates). (CY) control yoghurt, (SY) yoghurt with syrup, (WY) yoghurt with WPI, (WSY) yoghurt with WPI and syrup, (AY) yoghurt with albumin, (ASY) yoghurt with albumin and syrup.

Yoghurts made with syrup showed lower $L^{*}$ values (lightness) due to high total anthocyanin content on freeze-dried jaboticaba peel flour (Table 4), with significative difference $(P<0.05)$ between yoghurts without syrup that presented higher $L^{*}$ value on days 1 and 28 of storage. According to Fang (2015) anthocyanins are found in many dark-colored fruits, especially in high concentrations in the skin and are responsible for promoting color in these fruits. These values increased significantly on $28^{\text {th }}$ due to TAC decreasing value during the storage period.

Regarding the different treatments, it was verified that the value of $a^{*}$ (redness) (table 5) was high in the yoghurts added with syrup (SY, WSY, ASY), obtaining higher values on day 1 in the yoghurts containing protein, especially the yoghurt added with whey protein. However, after 28 days of storage, a significant diminish in $a^{*}$ values was observed in yoghurts added with protein, which was expected due to anthocyanins degradation during the storage period.

Regarding $b^{*}$ value (yellowness) (table 6 ) it is verified that there were significant differences $(P<0.05)$ between the treatments with and without syrup addition on the $1^{\text {st }}$ day, where more yellowish color was observed in the groups without syrup. Among the yoghurts added with syrup, a significant difference was observed in the yoghurt containing albumin (ASY), which was more yellowish. However, over the storage period, a significant increase in $b^{*}$ values $(P<0.05)$ was observed in all treatments. Similar results were found by Sung et al. (2015) which have used freeze-dried mulberry rich in anthocyanins. This compound is becoming an alternative to replace artificial food colorant furthermore color is a very important sensory acceptability.

\section{Conclusions}

The addition of syrup containing jaboticaba pulp and lyophilized jaboticaba peel flour in nonfat yoghurt made with proteins (WPI or albumin) showed differences in phenolic content and instrumental color parameters on experimental groups during the storage period. The yoghurt containing WPI and jaboticaba syrup showed a significant reduction in total phenolics and total anthocyanins content. However, yoghurt made with albumin and added with fruit syrup showed an increase in the total flavonoids content, demonstrating that the amount of phenolics compounds present in yoghurt at the end of the storage period may be related to protein type and phenolic compound type involved in the interactions. The data obtained in the color parameters reflected the anthocyanins degradation during the storage period. Future studies should be directed to determine what kind of interaction may occur between different types of proteins and phenolic compounds and how the degradation of these compounds during dairy product storage may be diminished.

\section{Acknowledgments}

The authors thank Coordination for the Improvement of Higher Education Personnel (CAPES) for the scholarship provided to C. A. M. Coentrão. 


\section{References}

ABE, L.; F. LAJOLO; GENOVESE, M. Potential dietary sources of ellagic acid and other antioxidants among fruits consumed in Brazil: jabuticaba (Myrciaria jaboticaba (Vell) Berg). Journal of the Science and Food Agriculture, v.92, n.8, p.1679-1687, 2011.

AINSWORTH, E.A.; GILLESPIE, K.M. Estimation of total phenolic content and other oxidation substrates in plant, tissues using Folin-Ciocalteu reagent. Nature Protocol, v.2, n.4, p.875-877, 2007.

CHEN, C.; CHI, Y.J.; ZHAO, M.Y.; LV, L. Purification and identification of antioxidant peptides from egg white protein hydrolysate. Amino Acids. v.43, n.1, p.457-466, 2012.

CHOUCHOULI, V.; KALOGEROPOULOS, N.; KONKELES, S.; KARVELA, E.; MAKRIS, D. P.; KARATHANOS, V. Fortification of yogurts with grape (Vitis vinifera) seed extracts. LWT- Food Science and Technology, v.53, n.2, p.522-529, 2013.

COSTA, M.P.; MONTEIRO, M.L.G; FRASAO, B.S.; SILVA, V.L.M.; RODRIGUES, B.L., CHIAPPINI, C.C.J.; CONTE-JUNIOR, C.A. Consumer perception, health information, and instrumental parameters of cupuassu (Theobroma grandiflorum) goat milk yogurts. Journal of Dairy Science, v.100, p.157-168, 2017.

DE SOUZA DE AZEVEDO, P.O.; ALIAKBARIAN, B.; CASAZZA, A.A.; LEBLANC, J.G.; PEREGO, P.; DE SOUZA OLIVEIRA, R.P. Production of fermented skim milk supplemented with different grape pomace extracts: Effect on viability and acidification performance of probiotic cultures. Pharma Nutrition, v.6, n.2, p.64-68, 2018.

DELIKANLI, B.; OZCAN, T. Improving the textural properties of yogurt fortified with milk proteins. Journal of Food Processing and Preservation, v.41, n.5, e13101, 2016.

DEMIRKOL, M.; TARAKCI. Z. Effect of grape (Vitis labrusca L.) pomace dried by different methods on physicochemical, microbiological and bioactive properties of yoghurt. LWT- Food Science and Technology, v.97, p.770-777, 2018.

DI MAIO, G.; PITTIA, P.; MAZZARINO, L.; MARASCHIN, M.; KUHNEN, S. Cow milk enriched with nanoencapsulated phenolic extract of jaboticaba (Plinia peruviana). Journal of Food Science and Technology, v.56, n.3, p.1165-1173, 2019.

FANG, J. Classification of fruits based on anthocyanin types and relevance to their health effects. Nutrition, v.31, p.1301-1306, 2015.

INADA, K.O.P.; OLIVEIRA, A.A.; REVORÊDO, T.B.; MARTINS, A.B.N.; LACERDA, E.C.Q.; FREIRE, A.S.; BRAZ, B.F.; SANTELLI, R.E.; TORRES, A.G.; PERRONE, D.; MONTEIRO, N.C. Screening of the chemical composition and occurring antioxidants in jabuticaba (Myrciaria jaboticaba) and jussara (Euterpe edulis) fruits and their fractions. Journal of Functional Foods, v.17, p.422-433, 2015.

KIM, B. G.; YANG, S.M.; KIM, S.Y.; CHA, M.N. Biosynthesis and production of glycosylated flavonoids in Escherichia coli: current state and perspectives. Applied Microbiology and Biotechnology, v.99, n.7, p.2979-2988, 2015.

LANNI, A.; INOSSA, D.; MARTINO, C.; BENNATO, F.; MARTINO, G. Short communication: Compositional characteristics and aromatic profile of caciotta cheese obtained from Friesian cows fed with a dietary supplementation of dried grape pomace. Journal of Dairy Science, v.102, n.2, p.1025-1032, 2019.
LEE, J.; DURST, R.; WROSTAD, R. Determination of total monomeric anthocyanin pigment content of fruit juices, beverages, natural colorants, and wines by the $\mathrm{pH}$ differential method: Collaborative study. Journal of AOAC International, v.88, n.5, p.269-1.278, 2005.

LEE, S.H.Y.; HUMPHRIES, D.J.; COCKMAN, D.A.; GIVENS, D.I.; SPENCER, J.P.E. Accumulation of Citrus Flavanones in Bovine Milk Following Citrus Pulp Incorporation into the Diet of Dairy Cows. EC Nutrition, v.7, p.143-154, 2017.

LEITE-LEGATTI, A.; BATISTA, A.; DRAGANO, N.; MARQUES, A.; MALTA, L.; RICCIO, M.; EBERLIN, M.; MACHADO; SILVA, A.L.; RUIZ, A.; CARVALHO, J.; PASTORE GAND JUNIOR, M. Jaboticaba peel: antioxidant compounds, antiproliferative and antimutagenic activities. Food Research International, v.49, n.1, p.596-603, 2012.

LIN, J.; TANG, C.Y. Determination of total phenolic and flavonoid contents in selected fruits and vegetables, as well as their stimulatory effects on mouse splenocyte proliferation. Food Chemistry, v.101, n.1, p.140-147, 2007.

MERCAN, E.; SERT, D.; KARAKAVUK, E.; AKIN, N. Effect of different levels of grapeseed (Vitis vinifera) oil addition on physicochemical, microbiological and sensory properties of settype yoghurt. International Journal of Dairy Technology, v.71, p.34-43, 2017.

M'HIRI, N.; IOANNOU, I.; BOUDHRIOUA, N.M.; GHOUL, M. Effect of different operating conditions on the extraction of phenolic compounds in orange peel. Food and Bioproducts Processing, v.96, p.161-170, 2015.

REIS, R.C.; CASTRO, V.C.; DEVILLA, I.A.; OLIVEIRA, C.A.; BARBOSA, L.S.; RODOVALHO, R. Effect of drying temperature on the nutritional and antioxidant qualities of Cumari Peppers from Pará (Capsicum chinense Jacqui). Brazilian Journal of Chemical Engineering, v.30, n.2, p.337-343, 2013.

ROMÃO, P.V.M.; PALOZI, R.A.C.; GUARNIER, L.P.; SILVA, A.O.; LARENÇONE, B.R.; NOCCHI, S.R.C.; MOURA, C.F.S.; LOURENÇO, E.L.B.; SILVA, D.B.; JUNIOR, A.G. Cardioprotective effects of Plinia cauliflora (Mart.) Kausel in a rabbit model of doxorubicin-induced heart failure. Journal of Ethnopharmacology, v.242, 112042, 2019.

SCIBISZ, I.; ZIARNO, M.; MITEK, M. Color stability of fruit yogurt during storage. Journal of Food Science and Technology, v.56, n.4, p.1997-2009, 2019.

SILVA, V.L.M.; SILVA, A.C.O.; COSTA-LIMA, B.R.; CARNEIRO, C.S.; CONTE-JUNIOR, C.A. Stability of polyphenols from blueberry (Vaccinium corymbosum L.) in fermented dairy beverage. Journal of Food Processing and Preservation, v.41, n.6, e13305, 2017.

SINGH, A.; GEVEKE, D.J.; JONES, D.R.; TILMAN, E.D. Can acceptable quality angel food cakes be made using pasteurized shell eggs? The effects of mixing factors on functional properties of angel food cakes. Food Science and Nutrition, v.7, n.3, p.987996, 2019.

SUNG, J.M.; KIM, Y.B.; KUM, J.S.; CHOI, Y.S.; SEO, D.H.; CHOI, H.W.; PARK, J.D. Effects of freeze-dried mulberry on antioxidant activities and fermented characteristics of yogurt during refrigerated storage. Korean Journal for Food Science of Animal Resources, v.35, n.6, p.807-814, 2015.

ULRIH, N.P. Analytical techniques for the study of polyphenolprotein interactions. Critical Reviews in Food Science and Nutrition, v.57, p.2144-2161, 2015. 
XIAO, J.; CAO, H.; WANG, Y.J.; ZHAO, W.X. Glycosylation of dietary flavonoids decreases the affinities for plasma protein. Journal of Agriculture and Food Chemistry, v.57, n.15, p.66426648, 2009.

XIAO, J.; MAO, F.; YANG, F.; ZHAO, Y.; ZHANG, C.; YAMAMOTO, $\mathrm{K}$. Interaction of dietary polyphenols with bovine milk proteins: molecular structure-affinity relationship and influencing bioactivity aspects. Molecular Nutrition and Food Research, v.55, n.11, p.1637-1645, 2011.
YILDIRIM-ELIKOGLU, S.; ERDEM,.Y.K. Interactions between milk proteins and polyphenols: Binding mechanisms, related changes, and the future trends in the dairy industry. Food Reviews International, v.34, n.7, p.665-697, 2017. 